\title{
Investigating the Effects of Web-Based Science Material for Guided Inquiry Approach on Information and Communication Skills of Students
}

\author{
Ümmühan Ormanc1* \\ Bursa Uludag University, Faculty of Education, Bursa, Turkey, 0000-0003-3669-4537
}

Salih Çepni

Uludag University, Faculty of Education, Bursa, Turkey, 0000-0003-2343-8796

\begin{tabular}{ll}
\hline \hline Article history & In parallel with the development of technology and increase in \\
Received: & knowledge, learning-teaching environments have changed, and an \\
Received in revised form: & understanding has taken into basis that students are active and \\
11.02 .2020 & responsible for their own learning. In accordance with this situation, \\
inquiry-based learning approach and technology integration have come & to an important point in science curricula in our country. In the study, it \\
Accepted: & was aimed to investigate the effectiveness of web-based science \\
Key words: & material developed on the guided inquiry approach on students' \\
Inquiry, information and & information and communication skills. In the current study, embedded \\
communication skills, web- & design was selected amongst mixed methods. First, web-based material \\
based, science material. & was developed compatible with the guided inquiry approach for the \\
& systems in our body unit at sixth grade. Then, the developed material \\
& was applied during eight weeks by three teachers in three different \\
& classes and its effectiveness was examined. A total of 155 sixth grade \\
& students, 71 of whom were in the experimental group and 84 in the \\
& control group, participated in the study. In the study; "Information and \\
& Communication Skills Perception Scale" was used as a quantitative \\
& data collection tool and an observation form was used as the qualitative \\
& data collection tool. As a result of the study; although there was an \\
& increase in the information and communication skills perception scores \\
& of the students in the experimental group in which the web-based \\
& science material was applied according to the guided inquiry approach, \\
& it was understood that this difference was not significant [t(70)=-3.76, \\
p >.05]. Even though there is an increase in information and \\
communication skills, it is thought that this increase is not significant in \\
terms of the students' perceptions of information and communication \\
skills as these students were born into the technology age, developed \\
high perception towards information and communication skills through \\
their own tablets, computers, phones and other similar medium.
\end{tabular}

\section{Introduction}

In parallel with the rapidly increasing information and developing technology, training programs are updated and especially developing technologies are tried to be integrated into classroom environments. In the digital world in the present day, the position of the computer 
and information communication technology remains on the front row (Shanmugam, \& Balakrishnan, 2019). As Aktaş, Gökoğlu, Turgut and Karal (2014) stated, the integration of information and communication technologies (ICT) into education has started to gain momentum all over the world with the increasing use of ICT in the daily life, the recognition of its benefits and the decrease in technology usage age. ICT make web-based/supported courses stand out (Cook, 2007) improving traditional teaching methods via providing educational presentations as well as novel ways to innovate pedagogical strategies (Khalifa \& Lam, 2002). Today, traditional education is transformed into web-supported education and enrichment of web-supported education is possible with certain applications (Birbir \& Kanburoğlu, 2018). With technology integration into education, it can be said that similar situation has been realized in science courses and information and communication technologies have been integrated into science programs. Integrating ICT into science programs begins with the use of appropriate ICT tools (such as computer, software and hardware) when organizing learning and teaching activities and continues with the use of appropriate materials.

When the science programs (Ministry of National Education-MoNE 2013; 2018) considered, it is witnessed that inquiry based learning forms the basis and technology integration has started to gain importance with this very method. Together with the rapid developments in ICT and chances of inquiry-based learning processes; related research came into play with the combined use of technology-assisted and inquiry-based teaching (Sar1 \& Güven, 2013). As can be understood, inquiry approach is a suggested approach to be used in our country, but the importance attached to web-supported materials has been on the increase with the advances in technology. There are also studies observed in this area in the relevant literature (Applebaum, Vitale, Gerard \& Linn, 2017; Baldwin, 2012; Fang et al., 2016; Kim, 2011; Wongwatkit, Panjaburee \& Srisawasdi, 2017). It can arguably be said that the recent study is an example of this situation. In this study, web-based science material was developed and applied in accordance with the guided inquiry approach regarding the systems in our body unit at sixth grade. The main reason for the selection of the systems in our body unit is its being one of the main subjects of biology; a subject that students should 'memorize' and usually have trouble in understanding. Apart from these it constitutes a suitable course for technology integration. When the literature was examined, it was found that researches were generally conducted about participant achievement, performance and positive effects. However, it was found out that very few variables (inquiry, creative thinking) were considered as regards the skill dimension. To that end it is thought that focusing on the skill dimension, especially with emphasize on skills that would be associated with technology, might contribute to the literature. To illustrate, Avsec and Kocijancic (2016) examined the effects of technologysupported inquiry-based learning on technological literacy. In this context, it is thought that there are deficiencies in the field and the number of studies should be increased. Thereupon it is aimed to investigate the effects of the developed material on information and communication skills.

Information and communication skills are among the $21^{\text {st }}$ century skills (ACT21S, 2018; Chu et al., 2012; Hilton, 2010; MoNE, 2013; P21, 2018) and it would be fair to state that the development of these skills is essential in science education. With respect to inquiry-based learning it is believed that the material used will have positive effects on students' informatics and communication skills, since it enables students to plan by questioning, communicating and selecting appropriate evidence (Duran, 2016; Hilton, 2010). In fact nowadays informatics and communication skills are gaining importance with the developments in technology along with the increase in the variety of interaction patterns such as group work. Bearing in mind 
the integration of technology in the developed material with the importance of students' doing research and working together, it was decided to examine the effect of the material on information and communication skills.

Thusly the research sentence of the study is as follows:

- Is there a significant difference between the information and communication skills and perceptions of the students in the control group and experimental group in which web-based science material used appropriate to the guided inquiry approach?

\section{Theoretical Framework}

\section{Inquiry-based learning}

Inquiry-based learning is an active learning approach where discovery, research and investigation are used in learning experiences and learning-teaching resources and activities are designed to support the research process (Levy et al., 2008). In other words, inquiry-based learning is an approach that encourages students to produce and test their own hypotheses and allows for the use of scientific method (Green, Elliott \& Cummins, 2004). Inquiry-based learning includes classroom environments consisting of student-centered and open-ended activities where the inquiry process is learned (Colburn, 2000; Maaß \& Artigue, 2013).

Inquiry-based learning process also enables students to integrate the information they have learned into their daily lives and supports their learning by doing-living (Tatar \& Kuru, 2006). In this process, students are empowered to become independent and free learning individuals (Gibson, 1998). In addition, inquiry-based learning supports the development of students' skills such as hypothetical and critical thinking (Agrusti, 2013), problem solving and decision-making (Friedel et al., 2008) and analytical thinking (Brayshaw \& Gordon, 2008). In light of these students may comprehend how scientists work and gain the basic skills of carrying out scientific research (Kubicek, 2005). Inquiry-based learning indeed means arousing curiosity and interest in students (Spronken-Smith, Bullard, Ray, Roberts \& Keiffer, 2008). In a nutshell, inquiry-based learning leads to significant improvements in students' cognitive, affective and skill dimensions.

The inquiry-based learning process continues as a cycle. The inquiry cycle is purely studentoriented and designed to support mental development (Tatar, 2006). The inquiry cycle steps proposed by Llewellyn (2014) are as follows: Inquisition, Acquisition, Supposition, Implementation, Summation and Exhibition.

\section{Web-based inquiry-based learning}

With the introduction of computer and internet to educational environments, teaching methods and techniques have been transferred to web-based environments. One of them is inquiry-based learning and it is detected that the integration of technology is possible in differing ways. As Hakverdi-Can and Sönmez (2012) stated, with the integration of computer technologies in teaching environments, there has been an increase in teachers' use of different applications including the internet. Web-supported learning is an environment where students can search for and what is more, construct their own knowledge base through the links and search features hence it is a suitable platform for constructivist learning theory to go hand-inhand with inquiry-based learning (Chumley-Jones, Dobbie \& Alford, 2002). 
Quintana, Zhang and Krajcik (2005) state that there is an enhanced focus on an online inquiry where students ask research questions, seek digital libraries or other sources of information, read, evaluate and synthesize information. In this study, the entire research cycle was carried out on the web and information and communication technologies were included in different stages. Therefore, some of the research questions were supported with animations or photographs, actually animations were frequently included in the process, and digital information sources became accessible when needed. In this way, every step of the inquiry cycle was assured to support with web and technology.

\section{Information and communication skills}

It can be said that with the increase in information and communication technologies and thinking about their place in our lives and learning environments, information and communication skills have begun to be articulated more and more each day. Information and communication technologies skills are associated with the ability to use digital technology, communication tools and/or networks to access, manage, integrate, evaluate and create information (Chu et al., 2012). In the developed material, it is thought that the students' information and communication skills will develop as a result of the study, because it contains multimedia objects, includes a web-based instruction, and students are asked to access and present information by discussing and researching.

\section{Method}

In the study embedded design- a mixed research method, is resorted to. Although the embedded design is the design type that emerges from the embedding of qualitative data into the experimental design, it provides a general procedure for the participation of qualitative data before/after/during an experiment (Creswell \& Clark, 2011; Delice, 2015). Since the experimental method was supported by qualitative data collection tool, it was considered appropriate to refer to embedded design. The process applied in the study is given in Table 1 .

Table 1. Symbolic representation of the design used in the research

\begin{tabular}{lllll}
\hline Groups & Pretest & Process & & Posttest \\
\hline $\begin{array}{l}\text { Experimental } \\
\text { group 1-2-3 }\end{array}$ & $\begin{array}{l}\text { Information and } \\
\text { commication skills } \\
\text { perception scale }\end{array}$ & $\begin{array}{l}\text { Web-based science material } \\
\text { in accordance with guided } \\
\text { inquiry approach }\end{array}$ & $\begin{array}{l}\text { Observation } \\
\text { form }\end{array}$ & $\begin{array}{l}\text { Information } \\
\text { communication } \\
\text { skills } \\
\text { pcale }\end{array}$ \\
\hline $\begin{array}{l}\text { Control grouption } \\
1-2-3\end{array}$ & $\begin{array}{l}\text { Information and } \\
\text { communication skills } \\
\text { perception scale }\end{array}$ & Science curriculum & Observation & $\begin{array}{l}\text { Information and } \\
\text { formmunication } \\
\text { perception } \\
\text { skills } \\
\text { scale }\end{array}$ \\
\hline
\end{tabular}

As can be followed in Table 1, courses were conducted with web-based science material appropriate to the guided inquiry approach in the experimental group, while the control group continued the courses according to the science curriculum. In the study, three experimental and three control groups were used, and the information and communication skills perception scale were used as pre-test and post-test. In addition, observations were used as a qualitative data collection tool throughout the process.

\section{Participants}

The study was conducted in three different secondary schools in Bursa. When selecting schools, it was ensured that they were in different regions with varying socio- 
economic levels in Bursa. In each school, courses were conducted with three different teachers and their two classes. The teacher $\mathrm{A}$ in the study is a person with nearly 10 years of experience, actively using the science laboratory, teaching the courses related to active learning approaches and integrating experiments into the courses. Teacher B has nearly 20 years of experience. The teacher uses the science laboratory and conducts experiments notthat-actively in the school and makes use of computers and interactive boards. Teacher $\mathrm{C}$ is a person who has approximately 30 years of experience, occasionally teaches with laboratory studies and technology usage and conducts the courses in a relatively more classical school of thought. Although there were some differences in the application processes of the teachers, all of them tried to use the developed material effectively.

In the study, one of the equivalent classes of each teacher was randomly assigned as experiment and control group. 45 students from middle school A, 58 students from middle school B and 52 students from middle school C participated in the study. Whilst 71 of the students were in the experimental groups, 84 were in the control groups.

\section{Material development process}

In this study, the material was developed for the Systems in Our Bodies unit at sixth grade in science course. The unit has 14 objectives and the given duration was total of 32 teaching hours. The inquiry cycle developed by Llewellyn (2014) was used to develop material for the unit. The process is as follows:

- Inquisition: A lead in to the process is realized so that students can start inquiry. Inquiry questions can be formed by using surprising events about the topic, observation results of any research, open-ended questions or demonstration experiments by the teacher. An event related to daily life, open-ended questions or animations were used in the preparation of the materials.

- Acquisition: At this stage, students try to recall their prior knowledge and use this information to solve the problem. In this process, students are expected to have group discussions or be involved in brainstorming activities.

- Supposition: At this stage of the inquiry cycle, the students are asked to make predictions so as to find a solution to the question in the questioning step.

- Implementation: At this stage, students design and implement experiments/ activities to solve the problem. Since the guided inquiry approach was used in the developed material, the teacher prepared the objectives and materials of the activity and presented these to the students. The students were asked to do the experiments or activities on their own.

- Summation: At this stage of the cycle, the students record and analyze their observations and results during the experiment/ activities.

- Exhibition: At this stage, students share their findings and new information with the whole class viz. with their teachers and peers.

After the completion of the preparations, the developed material was presented to expert opinion. For this purpose, two academicians in science education, one biologist and two science teachers examined the material. In line with the feedback from the experts, arrangements were made in the material. The experts proposed major changes in particular to the questions in the inquisition step. The experts' opinion is that the questions are usually in the form of a single answer question, and that some questions create problems in making students think. Accordingly, the questions were updated, and necessary changes were made. 
Then, the pilot implementation was realized for the material. Necessary steps were followed in line with the feedback provided in implementation and technology integration and web support were integrated into the material. For this purpose, concept cartoons were transformed into animation, some changes were made in animations and worksheets were prepared for experiments and activities. In addition, the transfer of all material to the web has been completed and the material has been finalized.

\section{Treatment}

During the implementation process, first of all, teachers were given training on the method. For this purpose, some issues were emphasized e.g. the method in the material, the implementation procedures. Second, the whole process was intended to be explained through a sample course. All teachers conducted their courses in the experimental groups on the website and completed the process in accordance with the prepared material. In the control group, the courses were taught in parallel with the science curricula and textbooks.

\section{Data collection tool}

In this study, information and communication skills perception scale was used in quantitative dimension and qualitative observations were used to complement the qualitative dimension, forming the data collection tools.

\section{Information and communication skills perception scale}

In this study, "the information and communication skills perception scale" was developed by the researchers. For this purpose, the definition of the Ministry of National Education (2011) was adopted for information and communication skills. These skills are composed of 5 sub-dimensions and 22 items. Likert type scaling was used in the scale and the responses can be given as strongly agree, agree, undecided, disagree, strongly disagree. Preliminary applications of the scale were carried out in middle schools in Bursa and 654 students participated in the study. The Cronbach Alpha internal consistency coefficient of the total score of the scale was 0.88 and Spearman Brown's two half reliability coefficient was 0.82. It was concluded that reliability coefficients above 0.70 were enough for the whole scale (Büyüköztürk, 2019) and that the measurement results were reliable according to these coefficients. Then, using a statistical package program, it was examined whether the data supported the five-dimensional factor structure that was revealed in the original. Maximum Likelihood was used as the analysis method in the study. $\mathrm{X}_{2} / \mathrm{sd}$ ratio was determined to examine if the data fit well to the model. It can be said that the compatibility between the study data and the model is quite good because the $\mathrm{X}_{2}$ /sd value is less than 5. Additionally, it was determined that the loads of the items ranged between 0.43 and 0.69 . According to this result, it was understood that the five factors in the model were confirmed by the items. When the error loads of the items were examined, it was determined that it varied between 0.52 and 0.81. According to these results, it can be declared that the errors of the items are at an acceptable level. The developed scale was applied to all participants as a pre and post-test.

\section{Observation form}

In the study, unattended observations were conducted to investigate the effectiveness of web-based science material in accordance with the guided inquiry approach. In the observation form, items to reach the appropriate information to the aim, to present information effectively, to improve communication skills were addressed. The observation 
form was prepared in a semi structured fashion. In the observation form, an assessment part was placed with five options: as always, often, sometimes, rarely and never. Besides, there are sections where comments can be written for each dimension. When the applications considered, a video was recorded in eight class hours in school A and observation forms were filled in seven times. Observation forms were used 12 times in school B and nine times in school C.

\section{Data analysis}

The information and communication skills perception scale, in which the students evaluated themselves, was used to target "Is there a meaningful difference between the information and communication skills and perceptions of the students in the experimental and control group using the web-based science material appropriate to the guided inquiry approach?" question. Though the scale was a five-point Likert type, it scored 1-2-3-4-5 and was analyzed using SPSS 23 program. Mann-Whitney U test was referred to with a view to comparing and checking the pre-test and post-tests of experimental and control groups in each school/teacher. Wilcoxon's Signed Rank Test was used for the comparisons of the pre-test and post-test of each school/teacher. Also, the common pre-tests data of the three schools/teachers were subjected to independent $t$ test, and then covariance analysis was performed for the posttests. However, for the common data of three schools/teachers, dependent $t$ test was used for pre-test and post-test comparison. Furthermore, the observation form was analyzed to determine the information and communication skills of the students. Whereas the descriptive statistics were used in structured sections in the observation form, descriptive analysis was preferred in the explanatory sections.

\section{Findings}

In order to find a solution to the problem, the data obtained from information and communication skills perception scale and observation form were analyzed and presented separately in the findings section.

\section{Findings from the information and communication skills (ICS) perception scale}

In this study, the effect of the web-based science material, which is appropriate to the guided inquiry approach, on the students' perception of information and communication skills was firstly examined separately for each teacher and then in a collective manner for three teachers.

\section{Findings obtained from all participants in the ICS perception scale separately}

Mann-Whitney $U$ test was preferred as the non-parametric test for the number of students belonging to $\mathrm{A}, \mathrm{B}$ and $\mathrm{C}$ teachers who performed the implementations was less than 30 in the experimental and control groups. It was diagnosed that there was no significant difference between the experimental group students and control group students in teacher A $(U=233.50, p>.05)$, teacher $B(U=386.50, p>.05)$ and teacher $C(U=272.00, p>.05)$. That is to say, it can be announced that the information and communication skills perception pre-test scores of the students in the experimental and control groups are equivalent to each other. Mann-Whitney $\mathrm{U}$ test results of the students of A, B and C teachers for the information and communication skills perception post-test scores are given in Table 2. 
Table 2. ICSP test scores of students in groups according to the U test results

\begin{tabular}{lllllll}
\hline Teacher & Group & $\mathbf{N}$ & Mean Rank & Sum of Ranks & $\mathbf{U}$ & \multirow{2}{*}{$\mathbf{p}$} \\
\multirow{2}{*}{$\mathrm{A}$} & Experimental & 22 & 24.27 & 534.00 & \multirow{2}{*}{225.00} & \multirow{2}{*}{.524} \\
& Control & 23 & 21.78 & 501.00 & & \multirow{2}{*}{.163} \\
\multirow{2}{*}{$\mathrm{B}$} & Experimental & 26 & 32.92 & 856.00 & \multirow{2}{*}{327.00} & \multirow{2}{*}{.861} \\
\hline \multirow{2}{*}{$\mathrm{C}$} & Control & 32 & 26.72 & 855.00 & \multirow{2}{*}{324.00} & \\
& Experimental & 23 & 26.09 & 600.00 & & \\
\hline
\end{tabular}

When Table 2 is examined, no significant difference is spotted among the post-test scores of the control and experimental group scores of the students of teacher $A(U=225.00, p>.05)$, teacher B $(\mathrm{U}=327.00, \mathrm{p}>.05)$ and teacher $\mathrm{C}(\mathrm{U}=324.00, \mathrm{p}>.05)$ on the information and communication skills perception test. Along these lines it can be proclaimed that the information and communication skills perception post-test mean rank of the students in the experimental and control groups are similar and generally the mean rank of the students in the experimental group are higher. Wilcoxon Signed Ranks test was implemented to determine the difference between pre-test and post-test information and communication skills perception scores of the students in the experimental and control groups of teachers $\mathrm{A}, \mathrm{B}$ and $\mathrm{C}$ and the results are given in Table 3.

Table 3. Wilcoxon signed rankings test results of the ICPS pre-test and post-test scores of the students in each group

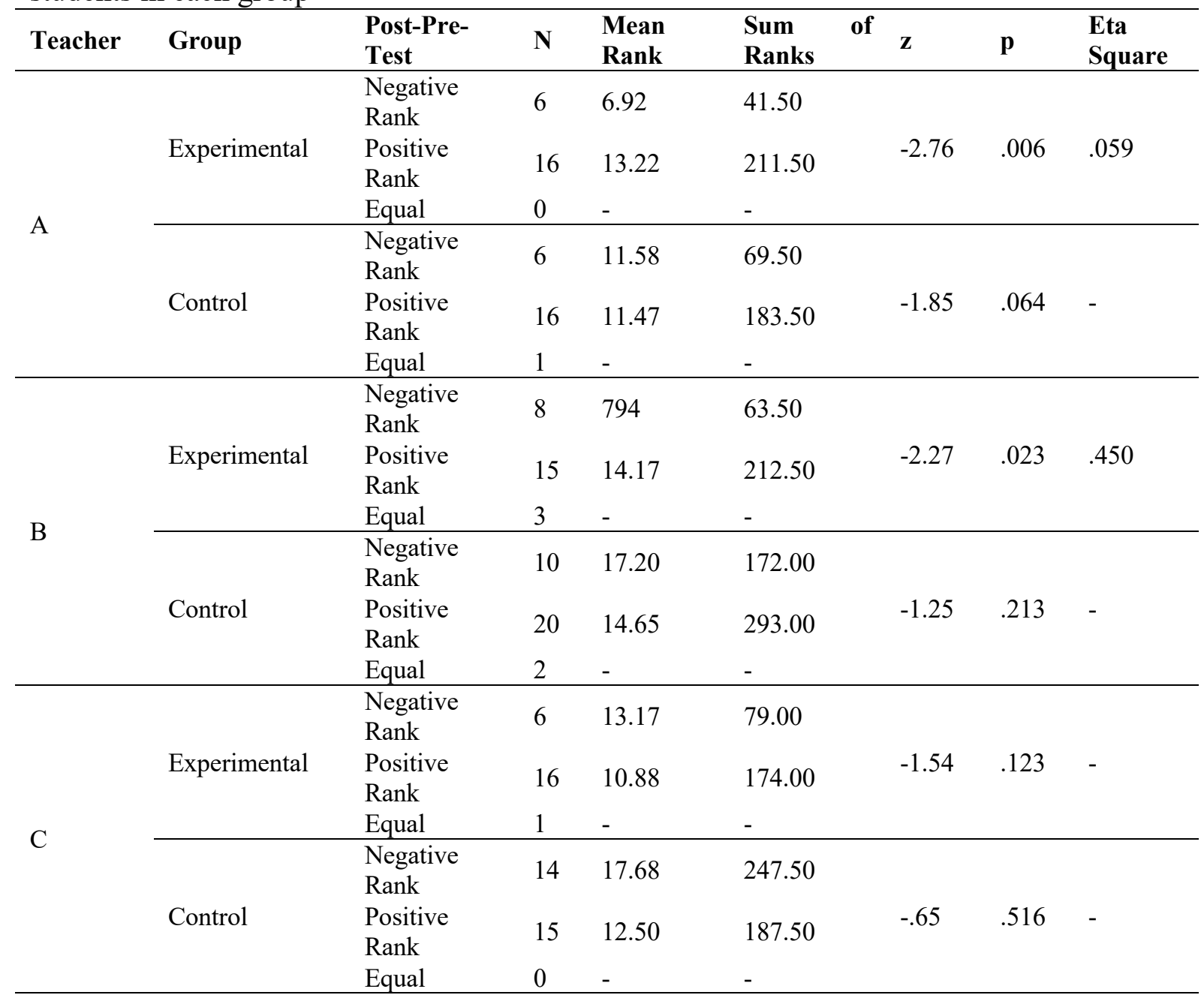


As it is seen in Table 3, there is a significant difference between pre and post-test information and communication skills perception scores of students in experimental group belonging to teacher $\mathrm{A}(\mathrm{z}=-2.76, \mathrm{p}<.05)$ and teacher $\mathrm{B}(\mathrm{z}=-2.27, \mathrm{p}<.05)$. Namely, the implemented material had a positive effect on improving students' perception of information and communication skills. Eta square value for this for Teacher A was .059 with $6 \%$ of the variance and for Teacher B with .450 with $45 \%$ of the variance and derived from the implemented teaching material. However, it was figured out that there was no significant difference between the information and communication skills perception scores of the students of teacher $\mathrm{C}$ prior to and after the implementation $(\mathrm{z}=-1.54, \mathrm{p}>.05)$. Moreover, there was no significant effect on the information and communication skills perception scores of control group students of $\mathrm{A}$ $(\mathrm{z}=-1.85, \mathrm{p}>.05), \mathrm{B}(\mathrm{z}=-1.25, \mathrm{p}>.05)$ and $\mathrm{C}(\mathrm{z}=-.65, \mathrm{p}>.05)$ teachers. That is, there was no significant increase between the pre-test and post-test scores of the students in the control group.

\section{Common findings from all participants on the ICP perception scale}

When the data obtained from the information and communication skills perception scale were examined by all participants collectively, Skewness value of the students in the experimental group was -.858 and Kurtosis value was .120, Skewness value of the students in the control group was -.835 and Kurtosis value was found to be 1.357 . Here it could be reported that the experimental and control group scores fulfill the normality value. In order to be able to determine whether there is a difference between the pre-test scores of the students in the experimental and control groups, t-test was performed for the independent groups. As a result, it was noted that students' information and communication skills perception pre-test scores did not display a significant difference compared to the groups $\left[\mathrm{t}_{(132.58)}=-1.28, \mathrm{p}>.05\right]$ so the information and communication skills perception scores of the students in the experimental (93.03) and control (95.51) groups are equal. Nevertheless, it was decided to perform covariance analysis to affirm a more reliable analysis. Normality, which is among the conditions required for covariance analysis, was obtained by looking at the kurtosis and skewness values. The correlation between the dependent and common variable, which is another condition, is calculated as 0.565 and it can be underlined that there is a positive and moderate relationship. Regression trends were found to be equal ( $p>.05)$ and analyzes were performed using Bonferroni test. Students' post-test information and communication skills perception post-test scores were slightly changed when the pre-test scores controlled. It was understood that the corrected mean of the students in the experimental group was 98.45 and the corrected mean of the students in the control group was 96.37. ANCOVA results as to whether there is a significant difference between the corrected posttest scores of the groups are given in Table 4.

Table 4. ANCOVA results according to corrected information and communication skills perception test scores of the groups

\begin{tabular}{lllllll}
\hline Source & Sum of Square & df & Mean Square & F & p & $\begin{array}{l}\text { Eta } \\
\text { Squared }\end{array}$ \\
\hline Pre-test (reg.) & 5680.83 & 1 & 5680.83 & 74.09 & .000 & .328 \\
Group & 165.63 & 1 & 165.63 & 2.16 & .144 & .014 \\
Error & 11653.91 & 152 & 76.67 & & & \\
Total & 1485471.00 & 152 & & & & \\
\hline
\end{tabular}

According to ANCOVA results, it was found that there was no significant difference between the information and communication skills perception corrected posttest scores according to the pre-test scores of the students in the experimental and control groups $\left[\mathrm{F}_{(1,152)}=2.16\right.$, 
$\mathrm{p}>$.05]. It was discerned that the information and communication skills perception post-test scores of the students in the experimental and control groups were similar.

The results of the dependent t-test for the significance of the difference between the pre-test and post-test information and communication skills perception scores of the students in the experimental and control groups are given in Table 5.

Table 5. T-test results of the students in the experimental and control groups on information and communication skills perception pre-test post-test scores

\begin{tabular}{lllllllll}
\hline Group & Test & N & X & S & df & t & p & Eta Square \\
\hline \multirow{2}{*}{ Experimental } & Pre & 71 & 93.03 & 13.25 & \multirow{2}{*}{70} & \multirow{2}{*}{-3.76} & \multirow{2}{*}{.000} & \multirow{2}{*}{.168} \\
& Post & 71 & 97.76 & 10.98 & & & \multirow{2}{*}{. } \\
\multirow{2}{*}{ Control } & Pre & 84 & 95.51 & 10.51 & \multirow{2}{*}{83} & -1.28 & \multirow{2}{*}{.205} & - \\
& Post & 84 & 96.95 & 10.36 & & & \\
\hline
\end{tabular}

It can be pointed out that there was a significant increase in information and communication skills perceptions of the students in the experimental group after the web-based science material appropriate to the guided inquiry approach applied $\left[\mathrm{t}_{(70)}=-3.76, \mathrm{p}<.05\right]$. Experimental application seemed to cause an increase in students' perception of information and communication skills. It can be voiced that the eta square size is .168 and $17 \%$ of the observed variance is due to the applied method. When the control group considered, it is understood that the applied science curriculum does not cause a significant increase on students' information and communication skills perception scores $\left[\mathrm{t}_{(83)}=-1.28, \mathrm{p}>.05\right]$. When the average scores considered, it can be manifested that there was an increase in the control group yet this increase was not significant. Descriptive statistics results of informatics and communication skills perception post-test scores are given in Table 6.

Table 6. Descriptive statistics of students' ICSP post-test scores according to teachers

\begin{tabular}{lllll}
\hline Teacher & N & Min-Max & X & SS \\
\hline Teacher A & 22 & $22-110$ & 97.27 & 8.42 \\
Teacher B & 26 & $22-110$ & 98.54 & 10.62 \\
Teacher C & 23 & $22-110$ & 97.35 & 13.62 \\
\hline
\end{tabular}

As seen in Table 6; the average of the post-test informatics and communication skills perception scale scores of the students was calculated as 97.27 in teacher A, 98.54 in teacher B and 97.35 in teacher C. In this context, it can be said that student posttest scores are very high and close to each other.

\section{Findings from the observation form}

In the study, observations were performed in order to determine the effect of developed web-based science material on students' information and communication skills in accordance with the guided inquiry approach. The findings obtained from the structured part of teacher A observation form are given in Table 6.

Table 6. Data obtained from teacher A observation form regarding information and communication skills

\begin{tabular}{lllllll}
\hline \multirow{2}{*}{ Codes } & \multicolumn{2}{c}{ Frequently } & \multicolumn{2}{c}{ Sometimes } & \multicolumn{2}{c}{ Rarely } \\
& f & $\mathbf{\%}$ & f & $\mathbf{\%}$ & f & \% \\
\hline Finding information, selecting the appropriate one & 6 & 17.1 & 1 & 2.9 & - & - \\
Developing appropriate knowledge & 4 & 11.4 & 3 & 8.6 & - & - \\
Presenting information in the most efficient manner & 2 & 5.7 & 5 & 14.3 & - & -
\end{tabular}




\begin{tabular}{lllllll} 
Improving communication skills & 2 & 5.7 & 5 & 14.3 & - & - \\
Developing basic computer skills & 2 & 5.7 & 4 & 11.4 & 1 & 2.9 \\
\hline Total & 16 & 45.7 & 18 & 51.4 & 1 & 2.9 \\
\hline
\end{tabular}

*"Always" and "Never" were removed from the table for not filled.

In the observations of teacher A's lessons (seven times); it is understood that $17.1 \%$ of the students found themselves frequently effective in searching, finding and selecting appropriate information. Nonetheless, it is thought that $14.3 \%$ of the students found themselves sometimes able to present information effectively, $14.3 \%$ of the students found themselves sometimes develop communication skills and $11.4 \%$ of the students found themselves sometimes develop basic computer skills. Given these $45.7 \%$ of the students frequently and $51.4 \%$ of the students sometimes use and develop information and communication skills. Similarly the data obtained from the explanatory part of the observation form are as follows: Firstly, it was seen that the students' interest in the interactive board was very high during the process. In addition to that, it was observed that most of the students used their books and notebooks more effectively in searching and finding information. It was recognized that the students were not very effective in presenting the information part, and even if there was a material they prepared, they were not effective in its introduction and usage. This situation may stem from the fact that the communication skills of the students are not very high. Table 7 shows the findings obtained from the observations realized in teacher B's course, another teacher for which the practices are performed.

Table 7. Data obtained from teacher B observation form related to information and communication skills

\begin{tabular}{lllllll}
\hline \multirow{2}{*}{ Codes } & \multicolumn{2}{c}{ Frequently } & \multicolumn{2}{c}{ Sometimes } & \multicolumn{2}{c}{ Rarely } \\
& f & $\mathbf{\%}$ & f & \% & f & \% \\
\hline Finding information, selecting the appropriate one & 9 & 15.0 & 3 & 5.0 & - & - \\
Developing appropriate knowledge & 1 & 1.7 & 10 & 16.7 & 1 & 1.7 \\
Presenting information in the most efficient manner & 5 & 8.3 & 5 & 8.3 & 2 & 3.3 \\
Improving communication skills & 4 & 6.7 & 7 & 11.7 & 1 & 1.7 \\
Developing basic computer skills & - & - & 7 & 11.7 & 5 & 8.3 \\
\hline Total & 19 & 31.7 & 32 & 53.3 & 9 & 15.0 \\
\hline
\end{tabular}

*“Always" and "Never" were removed from the table for not filled.

As can be seen from Table 7, twelve observations were made and it was observed that $15.0 \%$ of the students were frequently effective in searching, finding and selecting the most appropriate information. $16.7 \%$ of the students were sometimes effective in choosing the appropriate information. However, it was found that $11.7 \%$ of the students were sometimes effective in improving communication skills and $11.7 \%$ were sometimes effective in developing basic computer skills. In general, $53.3 \%$ of the students sometimes and $31.7 \%$ of the students frequently developed their information and communication skills. Similar findings were obtained from the observation notes and it was discovered that the students were effective in searching and finding information. Notwithstanding it was understood that the students searched for information solely using their books or doing so in the first weeks and generally did not tend to use other technologies. It was observed that internet was only used effectively in research assignments given as homework. Having said that it was observed that such search was carried out on the interactive board using search engines towards the last weeks. Additionally, it was seen that the students expressed themselves well in the stage of presenting the information. In the use of computer or technology, it can be said that there was 
no development for students' skills in parallel with being an active teacher. It was observed that only interactive materials were used by the students. It was observed that the students later used the interactive board more effectively in the process while they were initially hesitant. Finally, the findings obtained from the observations of the lessons of teacher $\mathrm{C}$ are shown in Table 8.

Table 8. Data obtained from the teacher $\mathrm{C}$ observation form on information and communication skills

\begin{tabular}{|c|c|c|c|c|c|c|c|c|c|c|}
\hline \multirow{2}{*}{ Codes } & \multicolumn{2}{|c|}{ Always } & \multicolumn{2}{|c|}{ Frequently } & \multicolumn{2}{|c|}{ Sometimes } & \multicolumn{2}{|c|}{ Rarely } & \multicolumn{2}{|c|}{ Never } \\
\hline & f & $\%$ & f & $\%$ & f & $\%$ & f & $\%$ & f & $\%$ \\
\hline $\begin{array}{l}\text { Finding information, selecting the appropriate } \\
\text { one }\end{array}$ & - & - & 6 & 13.3 & 3 & 6.7 & - & - & - & - \\
\hline Developing appropriate information & 1 & 2.2 & 4 & 8.9 & 3 & 6.7 & 1 & 2.2 & - & - \\
\hline $\begin{array}{l}\text { Presenting information in the most efficient } \\
\text { manner }\end{array}$ & - & - & 4 & 8.9 & 5 & 11.1 & - & - & - & - \\
\hline Improving communication skills & - & - & 4 & 8.9 & 4 & 8.9 & 1 & 2.2 & - & - \\
\hline Developing basic computer skills & - & - & 4 & 8.9 & 3 & 6.7 & 1 & 2.2 & 1 & 2.2 \\
\hline Total & 1 & 2.2 & 22 & 48.9 & 18 & 45.0 & 3 & 6.7 & 1 & 2.2 \\
\hline
\end{tabular}

A total of nine observations were made in the lessons of teacher $\mathrm{C}$ and $13.3 \%$ of the students were frequently effective in finding information and selecting the appropriate one. $11.1 \%$ of the students sometimes and $8.9 \%$ of the students were frequently successful in presenting information in the most effective way. Overall it was observed that $48.9 \%$ of the students were frequently and $45.0 \%$ were sometimes able to apply information and communication skills. In the observation notes, it is realized that students used books effectively in searching and finding information and they were successful in this process. It was noticed that they were not effective in presenting information and only use verbal expressions. Throughout the process, it was observed that there was a lot of interest in the interactive board and that the students wanted to use it continuously. It was observed that the students were very active in the animations which were in the form of drag-and-drop on the interactive board and they were effective in developing both technology and communication skills too. The data obtained from the observation forms in the lessons of the all participants in which the experimental applications were made are given in Table 9.

Table 9. Data obtained from the observation forms of all participants regarding information and communication skills

\begin{tabular}{|c|c|c|c|c|c|c|c|c|c|c|}
\hline \multirow{2}{*}{ Codes } & \multicolumn{2}{|c|}{ Always } & \multicolumn{2}{|c|}{ Frequently } & \multicolumn{2}{|c|}{ Sometimes } & \multicolumn{2}{|c|}{ Rarely } & \multicolumn{2}{|c|}{ Never } \\
\hline & f & $\%$ & f & $\%$ & f & $\%$ & $\mathbf{f}$ & $\%$ & $\mathbf{f}$ & $\%$ \\
\hline $\begin{array}{l}\text { Finding information, selecting the appropriate } \\
\text { one }\end{array}$ & - & - & 21 & 15.0 & 7 & 5.0 & - & - & - & \\
\hline Developing appropriate information & 1 & 0.7 & 9 & 6.4 & 16 & 11.4 & 2 & 1.4 & - & \\
\hline $\begin{array}{l}\text { Presenting information in the most efficient } \\
\text { manner }\end{array}$ & - & - & 11 & 7.9 & 15 & 10.7 & 2 & 1.4 & - & \\
\hline Improving communication skills & - & - & 10 & 7.1 & 16 & 11.4 & 2 & 1.4 & - & \\
\hline Developing basic computer skills & - & - & 6 & 4.3 & 14 & 10.0 & 7 & 5.0 & 1 & 0.7 \\
\hline Total & 1 & 0.7 & 57 & 40.7 & 68 & 48.6 & 13 & 9.3 & 1 & 0.7 \\
\hline
\end{tabular}

As it is seen in Table 10, it was observed that $15 \%$ of the students were frequently active in searching, finding and selecting the most frequent part. On the other hand, they were sometimes effective in finding the appropriate information with a frequency of $11.4 \%$ and in developing basic computer skills with a frequency of $10.0 \%$. In general, it can be said that $48.6 \%$ of the students were sometimes and $40.7 \%$ of the students were sometimes effective in the use and development of information and communication skills. 
When the qualitative and quantitative data collected in the study considered it was understood that the perception of information and communication skills of the students in the experiment group of teacher A was significantly increased, by way of explanation, the material had a positive effect on the students' perceptions. Withal no significant difference was found between the pre-test and post-test scores of the control group students and between the posttest scores of the experimental and control group. When the qualitative data on the reasons for the increase in the experimental group investigated, it was understood that the students were successful in reaching the information in the observations, but generally they used their notebooks and books in this process. Correspondingly it can be said that the students were partially good at presenting information and communication skills. Howbeit this situation was thought to be improved throughout the process. It was found that the students' interest was very high in interactive board, still they were hesitant to use it. In general, it can be stated that the informatics and communication skills of the students in the experimental group teacher A were improved, but this was not obvious.

In like manner it was understood that the students' perceptions of information and communication skills of the teacher B experiment group increased significantly, videlicet the material had positive effects on the students. After all, no significant difference was found between the pre-test and post-test scores of the control group students and between the posttest scores of experimental and control groups. When the data obtained from the observations were taken into account, it was understood that the students were successful in accessing the information and in this process, they started to use the books at the beginning and later on they started to use the internet. The students were sometimes good and sometimes had problems with information and communication skills. Granting all this, students' expression skills were strong and it was found that they were sometimes not successful in presenting the information. In the classroom, the interactive board was attracted great interest of the students and was used occasionally by the students. All the same, it can be said that the interactive board and technological tools are mostly used by teachers. It can be stated that the students' ICT skills and communication skills developed in the teacher B group.

It was found that there was no significant difference both between the pre-test and post-test comparisons of the students of teacher $\mathrm{C}$ in the experiment and control groups and the posttest comparisons of the students of teacher $\mathrm{C}$ in the experiment-control group. This meant there was no significant increase in information and communication skills scores of the students. Provided the observations in the experimental group considered, it can be said that the students tried to use their informatics and communication skills. However, this increase did not show up in the quantitative data collection tool. In the observations, it was found that the students generally reached the information and used the books at this stage and sometimes they were effective in presenting and communicating the information. Added to that, although the students were interested in the interactive board, it was understood that the students could not use it effectively because the technological tools were not made accessible by the teacher. In parallel with this situation, it is thought that the information and communication skills of the students did not increase significantly.

When all the three teachers are considered, it was understood that students' perceptions about information and communication skills increased significantly in the pre-test and post-test scores of the experimental group. In parallel with this situation, it was understood that the students in the experimental group were frequently effective in reaching information, while they were sometimes effective in presenting the information, communication skills and basic computer skills in observations. However, in the study, it was found that there was no 
significant increase in the comparison of the pre-test and post-test scores of the students in the control group and the comparison of the post-test scores of the experimental and control groups.

\section{Discussion and Conclusion}

In the study, although there was an increase in students' information and communication skills perception scores, it was determined that there was a significant difference between students who were only in the experimental groups of teacher A and B. In the literature, Pifarré Turmo and Argelagós Castañ (2008) concluded that the experimental group performing WebQuest performed better computerized activities (especially efficient search and managerial web information strategies) than the control group. Taking a look at the studies on the interactive board considered in the literature, it was understood that the use of interactive whiteboards positively affected the TBAP knowledge and self-confidence of teachers and prospective teachers (Akyüz, Pektaş, Kurnaz \& Memiş, 2014; Jang \& Tsai, 2012). In another study, it was found that pre-service teachers' attitudes towards information/information and communication technologies showed a significant difference in favor of the experimental group in the sub-dimension of biology course (Emre, Kaya, Özdemir \& Kaya, 2011a; Emre, Kaya, Özdemir \& Kaya, 2011b). Although similar results to the ones in the literature were not reached, it was concluded that information and communication skills apparently improved in more recent studies. Taking this into consideration, the material developed was thought to improve students' information and communication skills. It can be inferred as well that the students' skills such as communication, group work, expressing their own thoughts improved throughout the process because of the main reasons such as the continuation of lectures via interactive board and website, the use of multimedia objects such as animations, videos, and due to the effective use of these tools by the students and owing to adopting a student centered approach. In this context, for the development of information and communication skills, which are among the $21^{\text {st }}$ century skills gaining importance with the advent of technology, environments should be constructed in which students are active, able to express themselves and are responsible for their own learning. At this point, teachers have big tasks and students need to be given effective guidance to develop these skills.

In the study, it was found that there was no significant difference between the information and communication skills perception post-test scores of the students in the experimental and control groups in teachers A, B, C and in all. In addition, no significant difference was found between the teacher $\mathrm{C}$ experiment group students' perception scores of information and communication skills before and after the application. In their study Hakkari, Yeloğlu, Tüysüz and İlhan (2017) concluded that z-book did not cause significant differences in attitudes towards technology. This is an unexpected result of the study. The main reason for this may be that the scores obtained from the scale were very high. Information and communication skills are thought to be high enough due to students' being digital natives and on account of the fact that they generally have their own devices such as tablets, computers and telephones and other media of technological sort to express themselves. In this study, although there was an increase in information and communication skills of students, it was found that this increase was not significant as the average scores were very high. In addition to this, parallel to the use of interactive board and some websites or animations in the control group, there was an expected result that the students in the control group increased their information and communication skills. 
Even though there was no significant difference between the information and communication skills perception scores of the experimental and control group students, it was understood that the information and communication skills of the experimental group increased. This is supported by the findings from qualitative data. In the observations, students were found to be frequently effective in searching, in finding the appropriate information to the aim and in selecting the suitable one, while they were sometimes effective in finding relevant information, in communicating skills and developing basic computer skills. In general, it can be said that students were sometimes or frequently effective in using and improving their information and communication skills. It can be stated that there was an improvement in the information and communication skills of the students especially during the process of searching for, finding and selecting the appropriate information. It can be emphasized that this situation was akin to the fact that the inquiry process takes place in the study and the students take an active part in the process of reaching information. At this point, in the context of information and communication scores, it can be said that there was a difference between quantitative data collection tool and qualitative data collection tool. Although students' information and communication skills were not very high, it can be stated that their perceptions were very high. It was thought that this situation was a result of either the students' self-confidence or the lack of opportunities in learning environments. In this study, it can be said that both cases were valid. It was found that in some cases, such as the use of interactive whiteboards and computers, the teachers did not offer students any opportunities to use information and communication technologies. It can then be highlighted that in some cases students were not given enough opportunities. In addition, students were not very effective in presenting the results they obtained, however, in this context, it was found out that their scores were high on the perception scale. It can be underpinned that this result was reached in parallel with the higher self-confidence of the students. In the study, parallel to the findings from the qualitative and quantitative data, it was understood that although students' perception of information and communication skills was higher, their skills were slightly lower.

As a result of the study, it was found that the students' information and communication skills perception scale post-test mean scores were 97.76 in the experimental group and 96.95 in the control group. Considering that the maximum score that can be obtained was 110, it can be said that the students' average perception scores of information and communication skills were high. In the literature, Haznedar (2012) examined the ICT skill levels of university students and ICT skills of the students in the five-point Likert-type scale was found to be 4.2 that was high level of skill. In their studies, Amedeker and Yidana (2010) stated that the ICT skills of the students in the faculty of education were at the intermediate level. In addition, it was stated that most of the students' attitudes towards using ICT to learn science were good and receptive (Aladejana, 2007). Similarly, it can be said that information and communication skills were high in the studies conducted in this context. It is thought that this situation might result from students' being born in the age of technology, being intertwined with technology starting from young ages and growing in more democratic and promised families in parallel with the change in family structures. Again, it was considered that every student should be given the right to speak as much as possible in classrooms in order to solve the problems in terms of expressing themselves academically and presenting their own ideas.

When the results considered in general, it is thought that web-based inquiry-based learning did not result in a significant increase in students 'perceptions of information and communication skills due to students' perception levels' being very high at the beginning and although the results of the study increase, they did not differ significantly. In addition, it was 
understood that there was an increase in the information and communication skills and perceptions of the students in the groups where the material was applied, specifically there was an improvement in the information and communication skills of the students in qualitative data. This situation was thought to emerge in parallel with the interactive processing of the courses on the website, the inclusion of multimedia objects, and choosing approaches through which students were active. On the condition that the skills of students wished to be improved, it can be said that they need to be given more responsibility allowing them to express themselves, giving them opportunities to do research, and boosting their responsibility in their learning. In this way, it was thought that students' skills would develop over time. In addition to this, in the study, it was understood that the information and communication skills of the students were not very good in the qualitative data. Although students were generally good at finding information, they often used books and notebooks and could not use the internet effectively in their research. It was interesting to note that although the internet and the interactive board were an opportunity in the process, they were not used by the students. In presenting and communicating information, although some students were better, it was understood that these skills were low. However, considering the age and situation of the students, it was thought that presentation and communication skills would improve. Finally, although it was thought that the students were good at basic computer skills, they were not able to use these skills because there was not much opportunity during the implementations. In this context, it can be said that the students should be given opportunities in classrooms in order to develop and improve their skills.

\section{Suggestions}

- It was understood that interactive whiteboard or technology was used in a teacheroriented manner. In order to eliminate this situation, it is thought that the activities should be included to be performed by the students or the number of interactive materials should be augmented in the web-based materials. In order to improve the students' information and communication skills, the student's interaction with the materials should be made sure.

- In this study, the effect of web-based inquiry-based learning on students' information and communication skills was investigated. However, at this point, it was understood that there were some differences between quantitative and qualitative data. It is believed that conducting a similar study and examining it in depth will be an asset for the literature.

- For teachers to use information and communication technologies effectively, education should be given, and trainings should be practiced.

\section{Acknowledgement}

This study was written from the doctoral thesis of the first author.

\section{References}

ACT21S (2018). Assessment and teaching of $21^{\text {st }}$ century skills. It is obtained on 26.03.2018 at http://www.atc21s.org/.

Agrusti, G. (2013). Inquiry-based learning in science education. Why e-learning can make a difference. Journal of e-Learning and Knowledge Society, 9(2), 17-26. 
Aktaş, I., Gökoğlu, S., Turgut, Y. E., \& Karal, H. (2014). Teachers' opinions about FATIH project: awareness, foresight and expectations. Necatibey Faculty of Education Electronic Journal of Science and Mathematics Education, 8(1), 257-286.

Akyüz, H. İ., Pektaş, M., Kurnaz, M. A., \& Memiş, E. K. (2014). The effect of smart board centered micro-teaching activities on science teachers' technological pedagogical content knowledge (tpack) and their perceptions towards using smart board. Cumhuriyet International Journal of Education, 3(1), 1-14.

Aladejana, A. (2007). The implications of ICT and NKS for science teaching: Whither Nigeria. Complex Systems, 17, 113-124.

Applebaum, L. R., Vitale, J. M., Gerard, E., \& Linn, M. C. (2017). Comparing design constraints to support learning in technology-guided inquiry projects. Journal of Educational Technology \& Society, 20(4), 179-190.

Amedeker, M., \& Yidana, I. (2010, June). Science teacher trainees' perceptions about their information and communication technology skills in the university of education, Winneba, Ghana. EdMedia: World Conference on Educational Media and Technology, Toronto, Canada.

Avsec, S., \& Kocijancic, S. (2016). A path model of effective technology-intensive inquirybased learning. Journal of Educational Technology \& Society, 19(1), 308-320.

Baldwin, M. J. (2012). The comparative effects of a computer-based interactive simulation during structured, guided, and student-directed inquiry on students' mental models of the day/night cycle. Doctoral dissertation, Texas A\&M University, Texas.

Birbir, Y., \& Kanburoğlu, V. (2018). A web aided education model that can be used in power electronics course. Engineering Science and Technology, an International Journal, 21, $17-23$.

Brayshaw, M., \& Gordon, N. (2008). Inquiry based learning in computer science: A natural approach to learning. 3rd Learning Through Inquiry Alliance (LTEA) Conference: 'Inquiry in a Networked World', United Kingdom.

Büyüköztürk, Ş. (2019). Manual of data analysis for social sciences. Ankara: Pegem Academy Publishing.

Chu, S. K. W., Tavares, N. J., Chu, D., Ho, S. Y., Chow, K., Siu, F. L. C., \& Wong, M. (2012). Developing upper primary students' 21st century skills: inquiry learning through collaborative teaching and Web 2.0 technology. Hong Kong: Centre for Information Technology in Education, Faculty of Education, The University of Hong Kong.

Chumley-Jones, H. S., Dobbie, A., \& Alford, C. L. (2002). Web-based learning: sound educational method or hype? A review of the evaluation literature. Academic Medicine, 77(10), 86-93.

Colburn, A. (2000). An inquiry primer. Science scope, 23(6), 42-44.

Cook, D. A. (2007). Web-based learning: pros, cons and controversies. Clinical Medicine, 7(1), 37-42.

Creswell, J. W., \& Clark, V. L. P. (2011). Designing and conducting mixed methods research. (2nd ed.). Thousand Oaks, CA: Sage.

Delice, A. (2015). Mixed method design selection, Dede Y. \& Demir, S. B. (Ed.), Design and execution of mixed method research (Creswell, J. W. \& Plano Clark, V. L.). Ankara: An1 Publishing.

Duran, M. (2016). The effect of guide material developed based on inquiry-based learning on 6th grade students' competence for learning science. Journal of Theoretical Educational Science, 9(1), 85-110.

Emre, İ., Kaya, Z., Özdemir, T. Y., \& Kaya, O. N. (2011a, September). The effect of smart board usage on science and technology teacher candidates' attitudes towards 
information and communication technologies and their success in cell division. 5th International Computer \& Instructional Technologies Symposium, Elazığ, Turkey.

Emre, İ., Kaya, Z., Özdemir, T. Y., \& Kaya, O. N. (2011b, May). The effects of the use of smart board on the success of science and technology teacher candidates on cell membrane structure and their attitudes towards information technologies. 6th International Advanced Technologies Symposium (IATS'11), Elazı̆g, Turkey.

Fang, S. C., Hsu, Y. S., Chang, H. Y., Chang, W. H., Wu, H. K., \& Chen, C. M. (2016). Investigating the effects of structured and guided inquiry on students' development of conceptual knowledge and inquiry abilities: a case study in Taiwan. International Journal of Science Education, 38(12), 1945-1971.

Friedel, C., Irani, T., Rudd, R., Gallo, M., Eckhardt, E., \& Ricketts, J. (2008). Overtly teaching critical thinking and inquiry-based learning: A comparison of two undergraduate biotechnology classes. Journal of Agricultural Education, 49(1), 72-84.

Gibson, H. L. (1998, April). Case studies of an inquiry-based science programs' impact on students' attitude towards science and interest in science careers. National Association for Research in Science Teaching, 71st, SanDiego, CA.

Green, W. J., Elliott, C., \& Cummins, R. H., (2004). " Prompted" inquiry-based learning in the introductory chemistry laboratory. Journal of Chemical Education, 81(2), 239241.

Hakkari, F., Yeloğlu, T., Tüysüz, C., \& İlhan, N. (2017). Development of an instructional material for an enriched book relating to "interactions between chemical types" unit in the ninth grade chemistry curriculum and investigation its effects. Education and Science, 42(192), 327-348.

Hakverdi-Can, M., \& Sönmez, D. (2012). Learning how to design a technology supported inquiry-based learning environment. Science Education International, 23(4), 338-352.

Haznedar, Ö. (2012). The investigation of undergraduate students' information and communication technology skills and attitudes to e-learning in terms of different variables. Unpublished Master Thesis, Dokuz Eylül University, İzmir.

Hilton, M. (Ed.). (2010). Exploring the intersection of science education and 21st century skills: A workshop summary. National Academies Press.

Jang, S. J., \& Tsai, M. F. (2012). Exploring the TPACK of Taiwanese elementary mathematics and science teachers with respect to use of interactive whiteboards. Computers \& Education, 59(2), 327-338.

Khalifa, M., \& Lam, R. (2002). Web-based learning: effects on learning process and outcome. IEEE Transactions on Education, 45(4), 350-356.

Kim, H. (2011). Inquiry-based science and technology enrichment program: Green earth enhanced with inquiry and technology. Journal of Science Education and Technology, 20(6), 803-814.

Kubicek, J. P. (2005). Inquiry-based learning, the nature of science, and computer technology: New possibilities in science education. Canadian Journal of Learning and Technology, 31(1), 51-58.

Levy, P., Aiyegbayo, O., Little, S., Loasby, I., Powell, A., Stratford, J., ... Corry, S. (2008). Designing and sharing inquiry-based learning activities: LAMS evaluation case study. DeSILA Final Report, Centre for Inquiry-based Learning in the Arts and Social Sciences, University of Sheffield.

Llewellyn, D. (2014). Inquiry within: Implementing inquiry- based science standards. USA: Corwinn Press, Inc. A Sage Publications Company.

Maaß, K., \& Artigue, M. (2013). Implementation of inquiry-based learning in day-to-day teaching: a synthesis. ZDM Mathematics Education, 45(6), 779-795. 
Ministry of National Education (MoNE) (2011). Secondary school 9th grade physics curriculum. Ankara: Ministry of Education.

Ministry of National Education (MoNE) (2013). Primary education institutions (primary and secondary schools) science course (3rd, 4th, 5th, 6th, 7th and 8th grades) curriculum. Ankara: Ministry of Education.

Ministry of National Education (MoNE) (2018). Science curriculum (primary and middle school grades 3, 4, 5, 6, 7 and 8). Ankara: Ministry of Education.

P21 (2018). P21's framework for 21st century learning. It is obtained on 26.03.2018 at http://www.p21.org/about-us/p21-framework

Pifarré Turmo, M., \& Argelagós Castañ, E. (2008). Inquiry web-based learning to enhance information problem solving competences in science. J. Zumbach, N. Schwartz, T. Seufert \& L. Kester (Ed.). Beyond knowledge: the legacy of competence. Meaningful computer-based learning environments. United Kingdom: Springer.

Quintana, C., Zhang, M., \& Krajcik, J. (2005). A framework for supporting metacognitive aspects of online inquiry through software-based scaffolding. Educational Psychologist, 40(4), 235-244.

Sarı, U., \& Güven, G. B. (2013). The effect of interactive whiteboard supported inquiry-based learning on achievement and motivation in physics and views of prospective teachers toward the instruction. Necatibey Faculty of Education Electronic Journal of Science and Mathematics Education, 7(2), 110-143.

Shanmugam, K., \& Balakrishnan, B. (2019). Motivation in Information Communication and Technology-based science learning in Tamil schools. Jurnal Pendidikan IPA Indonesia, 8(1), 141-152.

Spronken-Smith, R., Bullard, J. O., Ray, W., Roberts, C., \& Keiffer, A. (2008). Where might sand dunes be on Mars? Engaging students through inquiry-based learning in geography. Journal of Geography in Higher Education, 32(1), 71-86.

Tatar, N. (2006). The effect of inquiry-based learning approaches in the education of science in primary school on the science process skills, academic achievement and attitude. Unpublished PhD Thesis, Gazi University, Ankara.

Tatar, N., \& Kuru, M. (2006). The effect of inquiry-based learning approach in science education on academic achievement. Hacettepe University Journal of Education, 31, 147-158.

Wongwatkit, C., Panjaburee, P., \& Srisawasdi, N. (2017). A proposal to develop a guidedinquiry mobile learning with a mastery learning mechanism for improving students' learning performance and attitudes in Physics. International Journal of Mobile Learning and Organization, 11(1), 63-86. 